\title{
PARIWISATA HALAL : PERLUKAH REKONSEPTUALISASI?
}

\section{Akhmad Saufi ${ }^{1}$, L. Edy Herman Mulyono${ }^{2}$, Baiq Lisdiana Apriani ${ }^{3}$, Siti Hamdiah $\mathbf{R}^{4}$, Idham Kholid ${ }^{5}$, Herman Jayadi ${ }^{6}$, Ega Dwi Putri $\mathbf{M}^{7}$ \\ 1,2 Faculty of Economics and Business, Mataram University, Indonesia. \\ Email: akh.saufi72@gmail.com \\ 3,4,5,6,7 Magister Manajemen Fakultas Ekonomi dan Bisnis Universitas Mataram}

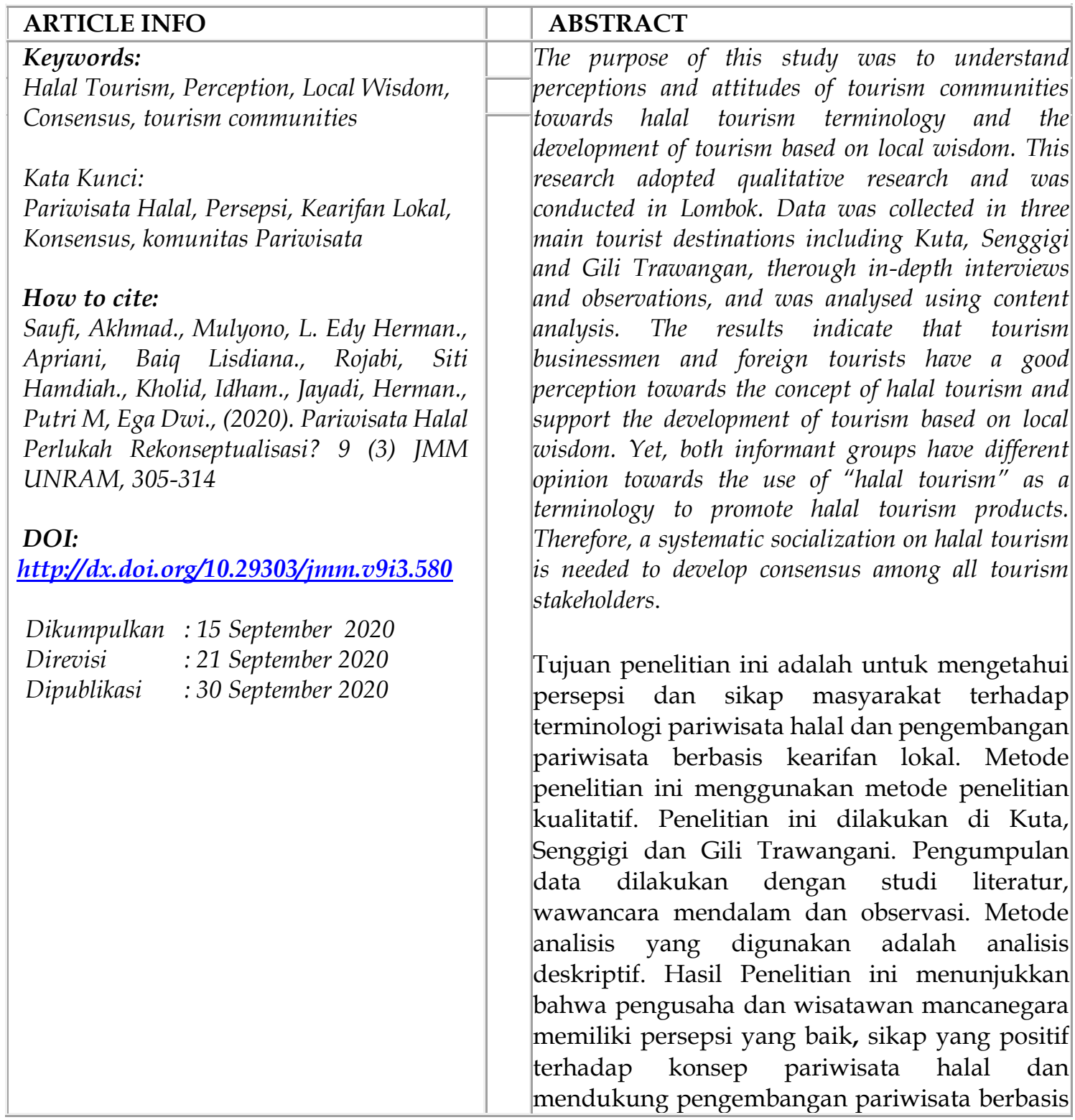




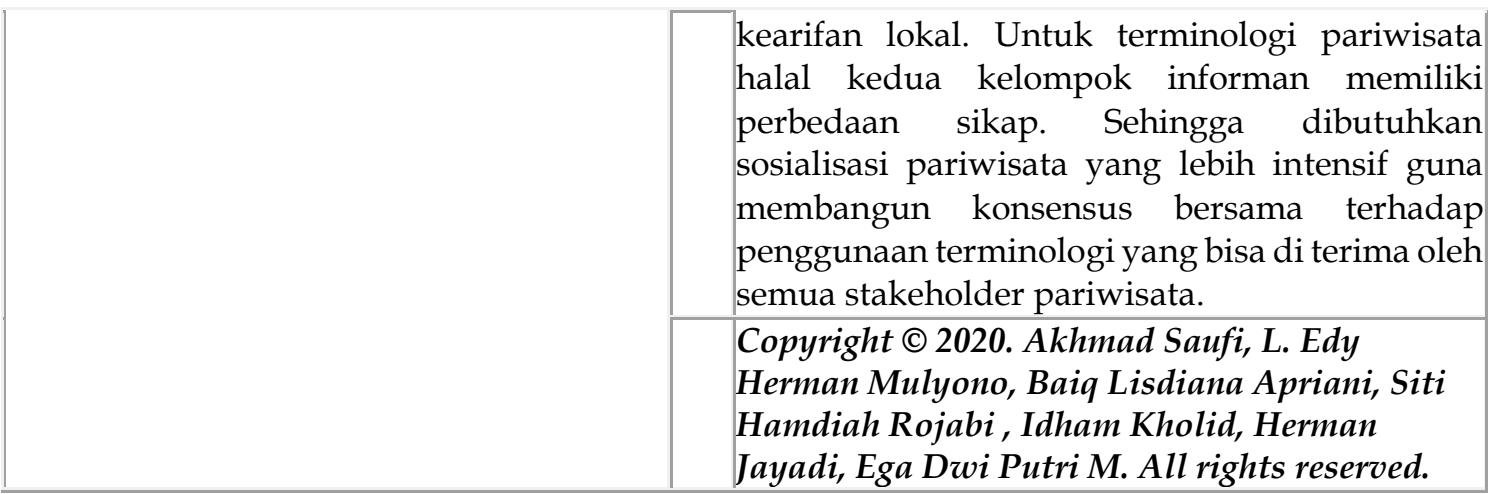

\section{PENDAHULUAN}

Lombok merupakan satu dari sepuluh provinsi di Indonesia yang di pilih oleh kementerian untuk mengembangkan pariwisata halal (IMTI, 2019). Lombok merupakan daerah yang mendapatkan award sebagai destinasi wisata halal terbaik di dunia pada tahun 2015 di acara World Halal Travel Award 2015 di Uni Emirat Arab (UEA). Lombok juga menjadi destinasi wisata halal terbaik di Indonesia (IMTI, 2019). Ini merupakan potensi besar untuk Lombok menjadi destinasi pariwisata halal kelas dunia. Dengan dipilihnya Lombok sebagai destinasi halal terbaik didunia, pemerintah daerah provinsi Nusa Tenggara Barat membuat aturan hukum tertulis untuk mewujudkan Lombok sebagai destinasi wisata kelas dunia. Peraturan daerah (Perda) no 2 tahun 2016 tentang pariwisata halal di buat sebagai payung hukum pengembangan pariwisata halal di Lombok.(Hidayat et al., 2019)

Namun dalam implementasinya, pengembangan pariwisata halal menjadi polemik di masyarakat. Istilah pariwisata halal menjadi bias dan multitafsir ketika istilah ini di artikan sempit dan kontra dengan model pembangunan pariwisata yang ada di Lombok saat ini. Pro-kontra terjadi di beberapa daerah di Indonesia (Permadi, Darwini, Retnowati, Negara \& Septiani, 2018).

Konsep halal dibuat oleh Kementerian Pariwisata karena melihat adanya potensi wisatawan asing dari negara mayoritas Muslim untuk datang ke Indonesia. Menurut Kementerian Pariwisata, potensi keuntungan dari Wisata Halal ini bisa mencapai 4000 triliun rupiah. Namun konsep Wisata Halal ditolak di berbagai daerah yang mayoritas non-muslim seperti di Danau Toba, Toraja, dan Bali. Hal ini dikarenakan sangat menyinggung agama lain, seolah-olah mereka adalah haram dan perlu untuk dihalalkan. Mereka juga berpendapat bahwa dengan adanya Wisata Halal tersebut akan mematikan kearifan lokal dan mengubah suatu daerah menjadi daerah agamis. Padahal apa yang dituduhkan tersebut adalah tidak benar, yang menjadi permasalahan tersebut adalah penggunaan kata "Halal" sehingga menimbulkan multitafsir di masyarakat, apalagi isu agama di Indonesia menjadi hal yang sangat sensitif (Hutagalung, A.F.N dalam brillio.net 2019).

Halal menurut Al - Qardawi (2013) adalah sesuatu yang diterima, diperbolehkan, artinya sesuatu yang diterima atau diperbolehkan dalam ajaran agama Islam. Sedangkan pariwisata halal di definisikan "Segala objek atau tindakan wisata yang diizinkan menurut ajaran Islam untuk digunakan atau dilibatkan oleh umat Islam dalam industri pariwisata". Definisi tersebut mempertimbangkan hukum Islam (syariah) sebagai dasar untuk memberikan produk dan layanan pariwisata kepada pelanggan target yang sebagian besar adalah Muslim, seperti hotel halal (hotel yang sesuai syariah), Resor Halal, restoran halal, dan perjalanan halal. Definisi tersebut mengklaim bahwa lokasi kegiatan tidak terbatas pada dunia Muslim. Oleh karena itu termasuk layanan dan produk yang dirancang untuk pelancong muslim di negara-negara muslim dan non-Muslim. Selain itu, definisi tersebut 
menganggap tujuan perjalanan belum tentu religius. Mungkin salah satu dari motivasi umum pariwisata.

Selain menawarkan wisata alam dan buatan, pariwisata halal juga dapat menampilkan budaya masyarakat yang terbentuk dari kebiasaan masyarakat sekitar yang tidak terlepas dari apa yang mereka yakini Pulau Lombok dengan mayoritas penduduk muslim dan dikenal dengan pulau seribu masjid mampu menampilkan budaya yang religius sesuai dengan budaya dan kebiasaan pada ajaran agama Islam, ini dapat diadopsi antara pengembangan pariwisata halal dengan kearifan lokal.

Pembahasan mengenai pariwisata berbasis lokalitas dimulai dari makana kearifan lokal. Kearifan lokal dalam kamus Inggris - Indonesia, terdiri dari 2 suku kata yaitu kearifan (wisdom) dan (local). Local berarti setempat dan wisdom sama dengan kebijaksanaan. Jadi local wisdom merupakan nilai-nilai kebajikan atau kebijaksanaan yang bersumber dari masyarakat itu sendiri, dibuat berdasarkan kebiasaan kemudian dijalankan dan dipatuhi oleh masyarakat. Kearifan lokal secara khusus berkaitan dengan budaya lokal yang tercermin dalam cara hidup suatu masyarakat lokal. Penekanannya adalah pada sifat kebudayaan sehari-hari yang berdasarkan pada kebiasaan dan repetitif, yang terus berlaku sepanjang masa dan mencakup ritual, simbol, dan upacara-upacara yang menghubungkan orangorang dengan tempat dan common sense tentang masa lalu (Nugraha et al., 2017).

Dalam pengembangan pariwisata, salah satu nilai kearifan lokal yang dapat digunakan adalah nilai inovasi, kegigihan, kebersamaan, musyawarah, lokalitas dan religius (Sudaryanto, 2018). (Ridwan et al., 2016) mengemukakan bahwa pada hakekatnya pembangunan pariwisata tidak bisa lepas dari sumber daya dan keunikan komunitas lokal, baik berupa elemen fisik maupun non fisik (tradisi atau budaya), yang merupakan unsur penggerak utama kegiatan wisata itu sendiri sehingga semestinya kepariwisataan harus dipandang sebagai kegiatan yang berbasis pada komunitas setempat atau biasa disebut berbasis kearifan lokal masyarakat setempat.

Dari penjelasan diatas bisa dipahami bahwa pariwisata halal merupakan pariwisata yang inklusif, tidak dibatasi tempat namun lebih mengedepankan bagaimana kebutuhan wisatawan muslim bisa difasilitasi dan memberikan kenyaman bagi mereka dalam perjalannya. Fenomena multitafsir terminologi pariwisata halal dan pro kontra konsep pariwisata halal di masyarakat (Surwandono et al., 2020) menjadi interest peneliti untuk diteliti lebih lanjut. Dalam penelitian ini analisis difokuskan pada perspektif komunitas pariwisata terutama para pengusaha pariwisata, dan wisatawan mancanegara tentang pariwisata halal. Sehingga rumusah permasalahan pada penelitian ini adalah: (1) Apakah perlu rekonseptualisasi istilah pariwisata halal?; (2) Bagaimana pengembangan pariwisata berbasis kearifan lokal?. Pertanyaan ini diajukan guna mendapatkan tujuan penelitian yakni: (1) Menganalisis dan mendiskripsikan persepsi pelaku usaha dan wisatawan mancanegara tentang rekonseptual pariwisata halal di Pulau Lombok; dan (2) Menganalisis dan mendiskripsikan pengembangan pariwisata berbasis kearifan lokal di Pulau Lombok.

\section{KAJIAN PUSTAKA}

\subsection{Pariwisata Halal}

Pariwisata halal memiliki beberapa istilah yang sering digunakan oleh kalangan peneliti yaitu 'Halal Tourism' and 'Islamic Tourism'dan lainnya seolah-olah konsep itu sama, cendikiawan muslim mendefisinikan halal itu sebagai apa yang di perbolehkan oleh Allah (Al-Qaradawi, 2007) sehingga halal diartikan mengacu pada aktivitas dalam pariwisata adalah apa saja yang diperbolehkan ajaran Islam (Battour, 2015) istilah Islamic hanya di gunakan pada apa saja yang berhubungan dengan agama seperti hukum-hukum 
islam, prinsip dan kepercayaan islam serta ibadah (Shaikh, 2004). Dari pemaparan sebelumnya dapat disimpulkan pariwisata halal adalah segala objek atau tindakan yang diperbolehkan menurut ajaran islam untuk digunakan atau dilibatkan dalam industri pariwisata, definisi tersebut dijadikan dasar untuk memberikan produk dan layanan pariwisata kepada pelanggan yang sebagian besar muslim seperti hotel halal, resort halal, restoran halal dan perjalanan halal, aktivitas pariwisata halal tersebut tidak hanya terbatas pada dunia muslim karena termasuk layanan dan produk yang di rancang untuk pelancong muslim dari negara muslim dan non-muslim (Battour, et al. 2015).

Pengertian lain tentang pariwisata halal mencakup wisata budaya, wisata alam, juga wisata buatan yang di kemas dengan prinsip dan nilai Islam. Karakter pariwisata halal adalah pengemasan nilai-nilai dan prinsip Islam yang dapat dinikmati oleh wisatawan dari berbagai latar belakang agama dengan memenuhi kebutuhan dasar wisatawan muslim seperti fasilitas ibadah, makanan dan minuman halal dengan jaminan halal serta tempat tinggal yang ramah wisatawan muslim (Subarkah, 2018). Pariwisata halal telah didfinisikan dengan berbagai cara oleh banyak ilmuan yang dirancang untuk memenuhi kebutuhan dasar wisatawan muslim yang terdiri dari berbagai komponen seperti makanan halal, hotel halal, paket perjalanan islami dan spa halal (El-Gohary, 2015). Dari berbagai definisi diatas dapat diartikan bahwa pariwisata halal adalah kegiatan wisata yang diperbolehkan tidak terlepas dari nilai dan prinsip ajaran Islam yang dapat di libatkan dalam industri pariwisata berupa layanan dan produk untuk memenuhi kebutuhan dasar wisatawan muslim dan nonmuslin berupa fasilitas (ibadah), makanan dijamin halal, tempat tinggal yang nyaman dan paket perjalanan yang halal.

\subsection{Kearifan Lokal}

Kearifan lokal merupakan bagian dari kehidupan masyarakat yang tidak bisa terpisahkan karena sudah menjadi peninggalan nenek moyang terdahulu seperti tradisitradisi budaya yang menjadi ciri khas masing-masing daerah. Pengembangan pariwisata berbasis kearifan lokal menjadi bagian dari produk kreatifitas manusia yang memiliki nilai ekonomi, salah satu cara pengembangan pariwisata berbasis kearifan lokal adalah pengemasan budaya lokal dalam bentuk festival (Sugiyarto, 2018) seperti tradisi yang ada di Lombok Tengah yaitu festival bau nyale. Pariwisata berkelanjutan tetap memperhatikan bagaimana pelestarian budaya yang sudah terbentuk di masyarakat untuk tetap bisa di jaga dengan memperaktikkan tradisi yang menjadi kearifan lokal, kearifan lokal bermula dari nilai-nilai adat istiadat, nilai-nilai keagamaan dan budaya asli yang secara alamai terkonstruk di dalam masyarakat untuk bagaiman beradaptasi terhadap lingkungan sekitar (Vitasurya et al., 2015).

Pendapat lain tentang pariwisata kearifan lokal adalah tradisi yang sudah ada dari beberapa generasi menjadi aset sosial yang berharga tetap di lestarikan dan diperkuat sehingga dijadikan sebagai daya tarik wisata bernilai ekonomi tinggi guna meningkatkan kesejahteraan masyarakat yang tinggal di kawasan wisata (Cahyaningrum, 2017). Destinasi wisata akan minati banyak orang bila kearifan lokal di kemas menjadi daya tarik wisata terlebih didukung oleh peraturan dareah yang mengatur pengembangan pariwisata berbasis kearifan lokal (Jupir, 2013), pariwisata berbasis kearifan lokal adalah kegiatan wisata yang dikemas dari tradisi budaya dan kearifan lokal yang menjadi daya tarik wisata bertujuan untuk melestarikan budaya yang bernilai ekonomi guna kesejahteraan masyarakat di kawan wisata. 


\subsection{Konsep dan Persepsi}

Konsep menjadi penting dalam upaya pemberian pemahaman tentang sesuatu, pariwisata halal membutuhkan konsep yang jelas agar pelaku wisata dan masyarakat dapat memahami secara menyeluruh. Belajar konsep merupakan hasil utama dari pendidikan yang juga dasar bagi proses-proses mental yang lebih tinggi untuk merumuskan prinsipprinsip dan generalisasi-generalisasi (Ratna Wilis Dahas, 1989). Pengertian lain tentang konsep adalah gagasan yang abstrak atau di abstrakkan didalam benak kita, juga sebagai gagasan atau pengertian yang di abstrakkan dari peristiwa konkret (Sumarsono, 2004). Konsep juga diartikan sebagai representasi abstrak dan umum tentang sesuatu yang bertujuan menjelaskan suatu benda, gagasan, atau peristiwa (Konsep Dalam Maxmanroe.com, 2019). Dari beberapa pengertian tentang konsep dapat diambil simpulan bahwa konsep merupakan suatu gagasan abstrak yang diabstrakkan dari peristiwa konkret bertujuan untuk menjelaskan suatu gagasan dan peristiwa yang dapat dipahami bersama. Jadi pariwisata halal merupakan suatu gagasan yang perlu dipahami bersama dari baru munculnya istilah pariwisata halal sehingga menjadi konsep pariwisata halal yang akan di terapkan oleh pelaku wisata, industri pariwisata, dan wisatawan.

Sementara itu, Ihsan (2008) mendefinisikan persepsi sebagai cara seseorang dalam melihat, menggambarkan atau menginterpretasikan sebuah objek, peristiwa, serta manusia. Ini sejalan dengan yang didefiniskan oleh Murianto (2014) bahwa persepsi adalah cara pandang, tindakan dan gambaran yang diberikan seseorang terhadap sesuatu yang berada disekitar lingkungannya baik itu positif maupun negatif. Dan orang-orang pada umumnya akan berprilaku dan bersikap sesuai dengan apa yang dipersepsikan.

Selain itu, Ramadhan (2009) mendefinisikan persepsi sebagai proses yang digunakan individu dalam memilih, mengorganisasikan, dan menginterprstasi suatu informasi untuk mendapatkan gambaran yang memiliki arti. Demikian juga Suranto (2010) mendefinisikan persepsi merupakan proses individu dalam memahami kontak atau hubungan dengan dunia disekelilingnya. Dalam hal ini, lingkup persepsi menyangkut rangsangan fisik dan ransangan lingkungan sekitar serta keadaan individu itu sendiri. Dengan demikian persepsi dapat dipengaruhi bentuk, gerak, suara, aroma, hingga atribut-atribut lainnya.

Berdasarkan uraian diatas dapat disimpulkan bahwa persepsi merupakan cara pandang dan interpretasi seseorang terhadap suatu objek yang dapat menentukan perilaku dan sikapnya terhadap objek tersebut. Sehingga karakter pribadi individu sangat mempengaruhi persepsi terhadap suatu objek.

\section{METODE PENELITIAN}

Penelitian ini mengadopsi metode kualitatif (qualitative research). Metode penelitian kualitatif sebagaimana yang diungkapkan Bogdan dan Taylor dalam L.J. Maleong (2018:4) sebagai prosedur penelitian yang menghasilkan data deskriptif berupa kata-kata tertulis atau lisan dari orang-orang dan perilaku yang dapat diamati. Penelitian kualitatif adalah penelitian yang bermaksud untuk memahami fenomena tentang apa yang dialami oleh subjek penelitian misalnya prilaku, persepsi, motivasi, tindakan, dll., secara holistik dan dengan cara deskripsi dalam bentuk kata - kata dan bahasa, pada suatu konteks khusus yang alamiah dan dengan manafaatkan berbagai metode alamiah (Moleong, L.J, 2018).

Data dalam penelitian ini berupa kata - kata dan tindakan para informan, foto dan data statistik (Lofland, dalam Moleong, 2018). Sementara itu penelitian ini dilakukan di tiga kawasan wisata utama yakni Kuta Mandalika, Senggigi dan Gili Trawangan. Subyek penelitian adalah sumber - sumber yang memungkinkan untuk meperoleh keterangan 
penelitian, informasi atau data. Untuk mencari informasi sebanyak mungkin, maka peneliti mengambil data dari berbagai sumber dengan tujuan untuk mendapatkan informasi yang. Adapun yang dijadikan subyek penelitian ini pelaku usaha pariwisata dan wisatawan. Para informan direkrut dengan pendekatan Purposive sampling dan accidental sampling. Kedua pendekatan ini digunakan untuk mendapatkan kelompok informan yang tepat. Purposive sampling dipergunakan untuk menyasar informan yang terdiri dari para usahawan parisiwasa dan wisatawan mancanegara yang mau berpartisipasi dalam penelitian ini. Sementara itu, accidental sampling dipilih karena para informan dijumpai di tempat tertentu tanpa ada perjanjian sebelumnya.

Alat yang akan digunakan dalam penelitian ini meliputi perekam, kamera, dan dan alat tulis. Teknik pengumpulan data dengan melakukan wawancara mendalam, observasi dan telaah pustaka. Sementara itu, data dianalisis dengan mengikuti langkah-langkah analisis data (Miles \& Huberman, 2009), yakni: (1) Reduksi Data yaitu kegiatan merangkum dan memilah hal-hal pokok yang ditemukan dalam catatan-catatan lapangan yang berhubungan dengan permasalahan penelitian. Kegiatan ini menggunakan teknik Coding yang selanjutnya disusun secara sistematis untuk dapat memberikan gambaran sesuai realita dan spesifik. (2) Display data digunakan untuk melihat gambaran keseluruhan hasil penelitian, baik yang berbentuk matrik atau pengkodean, dari hasil reduksi data dan display data itulah selanjutnya peneliti dapat menarik kesimpulan data memverifikasikan sehingga menjadi kebermaknaan data. Dan, (3) Verifikasi dilakukan dengan member-chek, trianggulasi dan audit trail, untuk menjamin kebermaknaan hasil penelitian. Sehingga dapat digunakan sebagai acuan menetapkan sebuah kesimpulan yang komprehensi.

\section{HASIL DAN PEMBAHASAN}

\subsection{Persepsi Wisatawan Mancanegara tentang Konsep Pariwisata Halal}

Pariwisata halal merupakan penambahan pelayanan dalam atraksi, akses dan aminiras (Sutono, 2015). Memenuhi kebutuhan dasar wisatawan muslim dalam perjalanannya (GMTI, 2016). Sebagai destinasi wisata halal terbaik di dunia, Lombok bukan hanya di kunjungi wisatawan muslim namun banyak juga di kunjungi oleh wisatawan non muslim. Wisatawan yang datang ke Lombok memiliki pengetahuan dan persepsi tentang istilah pariwisata halal.

"I think is good, I mean all belief system should be didicated with the rates muslim, with the rates tourism, with the rates christian, I think if we belief system should be dedicated for order people, they need system for certain food, they need certain place for pray and a certain time, I think is a good idea absolutely" (Wisman Eropa, Weste).

Wisatawan memahami pariwisata halal merupakan penyediaan fasilitas beribadah dan makan halal. Akan tetatapi wisatawan maupun masyarakat terkadang memahaminya dengan berbagai persepsi, ini disebabkan latar belakang Pendidikan mereka.

"No, I think they just not well-educated enough about this thing and it just depends on the people itself. Because they don't want to know the fact or whatever. And it is hard but if you are trying to like, ya just try like you, I saw you, you are so kind, you are so warm and process that you take to educate the people in nice way, a kind way" (Wisman, Natalia, England).

Wisatawan dan masyarakat yang memiliki pengetahuan tentang pariwisata halal akan menerima pariwisata halal dan ini menjadi tugas pemerintah untuk melakukan sosialisasi dan edukasi terhadap stakeholder pariwisata sehingga mereka memiliki pengetahuan tentang pariwisata halal. 
"I think it's very nice for moslem people to have a place they go to with everything they need. If you think about moslem culture, and as a woman. I do a sociate thing. So like do you have to go favorite and everything. maybe if you have halal tourism here and moslem people, you might not want other to prohibition. So that association, but well I don't to know what I thinking would like that, haha" (Jessica, Wisman Germany).

Pariwisata halal merupakan memberikan ruang kepada wisatawan muslim untuk mendaptkan kebutuhan mereka ketika liburan. Budaya dan kebutuhan wisatawan muslim perempuan juga sangat perlu di siapkan dan yang penting bagaiman tidak mengganggu dan membuat wisatawan lain merasa terlarang dalam beraktifikatas.

"I dont think so! I think is nice, like Indonesia can be such the best range of island, for the Muslim tourism, for Bali with the strong culture and you can have flores with that church for christian people, I think one of the special uniqe thing for Indonesia, that can be so diverse" (Wisman Eropa, Weste).

Dengan adanya pariwisata halal akan memberikan keragakan, keunikan bagi kepariwisataan Indonesia. Hal ini menjukkan bahwa wisatawan mancanegara memiliki persepsi yang positif tentang pariwisata halal. Ini merupakan modal dalam pengembangan pariwisata halal di Lombok. Walaupun konsep pariwisata halal belum familiar di wisatawan mancanegara eropa, wisatawan kelihatan kebingungan, butuh penjelasan dan bertanya kembali saat membahas terkait konsep pariwisata halal.

\subsection{Pariwisata Halal dalam Persepsi Pelaku Usaha}

Pengembangan konsep pariwisata Halal di Lombok tidak lepas dari dukungan para pengusaha. Peran pengusaha mampu mendorong pengembangan pariwisata karena pengusaha merupakan bagian dari unsur triple helix pengembangan pariwisata (Moelyono, 2010:237). Perkembangan pariwisata halal di Lombok mendapat dukungan dari pengusaha dan secara langsung maupun tidak langsung mempengaruhi pertumbuhan pariwisata halal.

"Saya setuju, karena memang satu kita pun sudah mendeklair kan bahwa Lombok ini adalah pulau seribu masjid kan, kami yang di pihak swastanya pastinya kan akan mendukung apa yang dikampanyekan oleh pemerintah dan kami juga khususnya di Aruna ya seperti tadi yang saya sampaikan kita mensupport wisata halalnya sepperti itu ya, kami punya musholla, tempat wudhu yang terpisah juga antara perempuan dan laki-laki, itu sebagai salah satu untuk pendukung pariwisata halal ini" (Manajer Pemasaran Hotel Aruna, Yari).

Pengusaha memberikan pelayanan tambahan di hotel mereka untuk memenuhi kebutuhan dasar wisatawan seperti musholla dan tempat wuda yang terpisah.

\subsection{Rekonseptualisasi Terminologi Pariwisata Halal}

Pada umumnya istilah atau terminologi pariwisata halal di dunia berkembang tidak dalam satu istilah, ada Islamic dan halal tourism (Battour, 2015). Halal menurut Sheikh Yusuf al-Qaradawi ketua International Union of Muslim Scholars dalam bukunya yang berjudul "Yang Sah dan Dilarang dalam Islam, istilah Halal didefinisikan sebagai "Apa yang diizinkan, sehubungan dengan yang tidak ada batasannya, dan perbuatan yang diperbolehkan oleh pemberi hukum, Allah," (Al-Qaradawi, hal. VII).

Sedangkan pariwisata dalam definisi UU No 10 Tahun 2009 "Pariwisata adalah berbagai macam kegiatan wisata dan didukung berbagai fasilitas serta layanan yang disediakan oleh masyarakat, pengusaha, Pemerintah, dan Pemerintah Daerah. Jadi Pariwisata Halal adalah kegiatan kunjungan wisata dengan destinasi dan industri pariwisata yang menyiapkan fasilitas produk, pelayanan, dan pengelolaan pariwisata yang memenuhi syari’ ah (Perda No 2 Tahun 2016). Sedangkan menurut Battour (2015) “Objek atau tindakan 
pariwisata apa pun yang diizinkan menurut ajaran Islam untuk digunakan atau dilibatkan oleh umat Islam dalam industri pariwisata". Sedangkan Islamic tourism menurut Carboni et al. (2014) mendefinisikan pariwisata Islam "Sebagai pariwisata sesuai dengan Islam, melibatkan orang-orang beragama Islam yang tertarik untuk menjaga kebiasaan keagamaan pribadi mereka saat bepergian".

Definisi pariwisata halal dan Islamic memilik perbedaan, Islamic lebih keranah hokum dan halal memiliki definisi yang universal mencakup semua kegiatan di dalamnya. Sehingga dalam penelitian ini dibutuhkan konsensus untuk pariwisata halal sehingga memiliki definisi yang disepakati Bersama oleh stakeholder pariwisata.

"I dont see what wrong with the word Halal, you know what I mean? For my perspective for traveling for long time, in traveling for three years around the world, so the world Halal make it known for every people... Halal destination, for people who want to come, they will come, for people who didn't come, there is someting againts their belief, dont worry about that, you know what I mean?" (Wisman Eropa, Weste).

"Kalay memang yah ibaratnya gini, halal dan tidak halal bahasanya jadi nngg ngak manis gitu ya apalagi di dunia usaha di dunia bisnis halal dan tidak halal emang menjadi kurang mengenakkan. Seandainya pun mau diubah menjadi muslim friendly itu jauh lebih baik karena itu lebih apa ya, lebih gampang diterima oleh masyarakat. Baik masyarakat yang khususnya di Indonesa, maupun masyarakat di luar sana gitu" (Manajer Pemasaran Hotel Aruna, Yari).

Ini menunjukkan perbedaan respon wisatawan dan pengusaha tentang terminologi pariwisata halal. Sehingga perlu adanya konsensus bersama tentang terminologi pariwisata halal, baik penggunaan di branding, konsep dan pemasaran.

\subsection{Wisata Lokalitas atau Kearifan Lokal}

Berdasarkan keterangan dari wisatawan dan pelaku usaha industri pariwisata bahwa penting untuk mengembangkan pariwisata kearifan lokal. Lombok merupakan daerah yang terkenal dengan pulau seribu masjid dan mayoritas masyrakatnya adalah muslim. Halal merupakan karakter dari masyarakat Lombok.

"....itu lebih baik kalua bisa di kombain, itu bisa jadi ciri khas dari lomboknya tetap ada, muslimnya yang bisa untuk menangkap market yang di luaran sana itu bisa lebh bagus ntuk bisa di kombinasikan..." (Manajer Pemasaran Aruna, Yari).

Pelaku usaha hotel mendorong pembangunan pariwisata halal yang di kombonasikan dengan kearifan lokal sehingga ada nilai tersendiri bagi Lombok sebagai destinasi wisata.

Untuk pariwisata berbasis lokalitas, terdengar lebih bagus. Contohnya Bali dengan ciri khas Hindu dan budayanya mampu ditampilkan sebagai produk wisata. Antara pariwisata dan budaya tidak mengganggu satu sama lain, melainkan dapat menjadi paket lengkap dari pariwisata yang ditawarkan. Dengan maksud untuk memperkuat budaya sendiri dan tidak terpengaruh dengan budaya asing yang datang. ".....they haven't change just because tourist is coming, ceremony and that's really nice. Cause the country have to know a little peace" (Jessica, Germany). 


\section{KESIMPULAN DAN SARAN}

Berdasarkan hasil penelitian dan pembahasan dapat ditarik kesimpulan bahwa tidak diperlukan rekonseptualisasi pariwisata halal di pulau Lombok dimana pelaku usaha pariwisata dan wisatawan mancanegara memiliki persepsi yang baik dan sikap yang positif terhadap implementasi konsep pariwisata halal di pulau Lombok. Namun, dari aspek terminologi terdapat perbedaan persepsi antara wisatawan mancanegara dan stakeholder pariwisata. Wisatawan merasa setuju dengan istilah pariwisata halal namun dalam perspektif stakeholder pariwisata menyarankan terminologi lain untuk menggantikan istilah pariwisata halal yakni moslem friendly. Sehingga, meskipun pemahaman mereka tentang pariwisata halal sesuai dengan konsep yang di kembangkan pemerintah namun masih perlu adanya konsensus dalam penetapan terminologi pariwisata halal yang dapat diterima oleh semua kalangan. Oleh karena itu, pemerintah NTB perlu melakukan sosialisasi dan melakukan FGD dengan para stakeholder sehingga semua stakeholder memahaminya dengan baik, dan mendaptkan istilah yang disepakati bersama. Selain itu konsep pengembangan pariwisata berbasis kearifan lokal akan lebih menarik jika di kombinasikan dengan pariwisata halal.

Penelitian ini masih mempunyai keterbatasan penelitian yang memerlukan peneliti selanjutnya untuk mengembangkan dan memperkaya kualitas penelitian ini. Adapun keterbatasan penelitian yang dimaksud yakni segmen responden yang dijadikan sebagai subyek penelitian masih terbatas, hanya mencakup wisatawan mancanegara dan pelaku usaha pariwisata. Sehingga belum diketahui apakah hasil dari penelitian tentang pentingnya rekonseptualisasi pariwisata halal akan sama jika ditinjau dari sudut pandang segmen responden yang berbeda, seperti dari sudut pandang wisatawan domestik, masyarakat umum, tokoh agama, tokoh masyarakat dan lainnya. Oleh karena itu perlu adanya penelitian lebih lanjut dengan mencakup segmentasi responden yang lebih luas.

\section{DAFTAR PUSTAKA}

Al-Qaradawi, Y. (2013). The lawful and the prohibited in Islam. Wisdom international school for higher education studies (WISHES). www.usislam.org , pdf , LawfulEProhibited

Battour, M., \& Ismail, M.N., 2015. Halal Tourism : Concepts, Practices, Challanges and Future. Tourism Management Perspectives 19: 150-154. https://doi.org/10.1016/j.tmp.2015.12.008

Cahyaningrum. (2017). Community Empowerment Based Local Wisdom In Tourism Of Bajo Community, Wakatobi, Volume 6, Issue 11, November 2017

Dahas, R.W. (1986). Teori-Teori Belajar. Penerbit Erlangga, Jakarta. 1989

El-Gohary, H., 2016. Halal Tourism, Is it Really Halal?. Tourism Management Perspectives 19:124-130. https://doi.org/10.1016/j.tmp.2015.12.013

Global Muslim Travel Index. 2018. Global Muslim Travel Index 2018. Mastercard and Halal Trip. Singapore

Hutagalung, A.F.N (2019). Pro kontra Wisata Halal, bagaimana sebaiknya? Di unduh https://www.brilio.net/creator/pro-kontra-wisata-halal-bagaimana-sebaiknyae37829.html

Hidayat, R., Awaluddin, M., \& Candra, C. (2019). Implementasi Kebijakan Pariwisata Halal Di NTB (Studi Implementasi Kebijakan Peraturan Daerah Provinsi NTB No.2 Tahun 2016 Tentang Pariwisata Halal). JIAP (Jurnal Ilmu Administrasi Publik). https://doi.org/10.31764/jiap.v6i2.645 
Indonesia Muslim Travel Index (2019). MasterCard-CrescentRating Indonesia Muslim Travel Index, Jakarta : Pew Research.

Jupir, M.M.. 2003. Implementasi Kebijakan Pariwisata Berbasis Kearifan Lokal (Studi Di Kabupaten Manggarai Barat). Malang: Fakultas Ilmu Administrasi Publik Universitas Brawijaya. Journal of Indonesian Tourism and Development Studies. E-ISSN: 2338-1647.

Moleong, L.J., 2007. Metodologi Penelitian Kualitatif. PT Remaja Rosdakarya. Offset. Bandung Nugraha, A. R., Perbawasari, S., \& Zubair, F. (2017). MODEL KOMUNIKASI PARIWISATA YANG BERBASISKAN KEARIFAN LOKAL. Jurnal The Messenger. https://doi.org/10.26623/themessenger.v9i2.468

Permadi, L. A et.al. 2018. Persepsi dan Sikap Masyarakat Terhadap Rencana Dikembangkannya Wisata Syariah (Halal Tourism) di Provinsi Nusa Tenggara Barat. Amwaluna. Vol. 2, No. 1 (Januari, 2018). Hal 39-57. ISSN 2540-8399.

Ridwan, M., Fatchan, A., \& Astina, I. K. (2016). POTENSI OBJEK WISATA TORAJA UTARA BERBASIS KEARIFAN LOKAL SEBAGAI SUMBER MATERI GEOGRAFI PARIWISATA. Jurnal Pendidikan - Teori, Penelitian, Dan Pengembangan. https://doi.org/10.17977/jp.v1i1.6601

Subarkah, A. R. (2018). Diplomasi Pariwisata Halal Nusa Tenggara Barat. Intermestic: Journal of International Studies. https:/ / doi.org/10.24198/intermestic.v2n2.6

Sudaryanto, A. (2018). NILAI-NILAI KEARIFAN LOKAL YANG DITERAPKAN DALAM PENGELOLAAN TANAH PARIWISATA SRI GETHUK DI BLEBERAN, PLAYEN, GUNUNG KIDUL. Mimbar Hukum - Fakultas Hukum Universitas Gadjah Mada. https://doi.org/10.22146/jmh.29153

Surwandono, S., Nursita, R. D., Diana, R., \& Meiliyana, A. (2020). Polemik Kebijakan Wisata Halal di Indonesia serta Tinjauannya dalam Maqashid Syariah. TSAQAFAH. https://doi.org/10.21111/tsaqafah.v16i1.3594

Sutono, A. (2019). Wonderful Halal Tourism For People Quality Of Life. Kementrian Pariwisata. Jakarta

Sumarsono. (2004). Buku Ajar Filsafat Bahasa, Penerbit Gramedia Widia Sarana Indonesia, Jakarta. 2004

Sugiyarto. (2018). Pengembangan Pariwisata Berbasis Budaya dan Kearifan Lokal, Jurnal Administrasi Bisnis, Volume 7, Nomor 1, Maret 2018, pp. 45-52

Vitasurya, V. R., Pudianti, A., Purwaningsih, A., \& Herawati, A. (2015). Kearifan lokal daam Pengelolaan Lingkungan desa wisata Kalibiru, di D.I Yogyakarta, dipresentasikan pada. Prosiding Seminar Nasional SCAN\#6 Universitas Atma Jaya Yogyakarta. 